\title{
Correction to: Comparative efficacy, safety and durability of dolutegravir relative to common core agents in treatment-naïve patients infected with HIV-1: an update on a systematic review and network meta- analysis
}

Katharina Nickel ${ }^{1}$, Nicholas J. A. Halfpenny ${ }^{2}$, Sonya J. Snedecor ${ }^{3}$ and Yogesh Suresh Punekar ${ }^{4^{*}}$

Correction to: BMC Infect Dis 21, 222 (2021)

https://doi.org/10.1186/s12879-021-05850-0

Following publication of the original article [1], the authors identified errors in Figs. 3a, b and 4. The correct figures are given below.

The original article has been corrected.

The original article can be found online at https://doi.org/10.1186/s12879021-05850-0

* Correspondence: yogesh.q.punekar@gsk.com

${ }^{4}$ ViiV Healthcare, GSK House, 980 Great West Rd, Brentford, Middlesex TW8

9GS, UK

Full list of author information is available at the end of the article

(c) The Author(s). 2021 Open Access This article is licensed under a Creative Commons Attribution 4.0 International License, which permits use, sharing, adaptation, distribution and reproduction in any medium or format, as long as you give appropriate credit to the original author(s) and the source, provide a link to the Creative Commons licence, and indicate if changes were made. The images or other third party material in this article are included in the article's Creative Commons. licence, unless indicated otherwise in a credit line to the material. If material is not included in the article's Creative Commons licence and your intended use is not permitted by statutory regulation or exceeds the permitted use, you will need to obtain permission directly from the copyright holder. To view a copy of this licence, visit http://creativecommons.org/licenses/by/4.0/. The Creative Commons Public Domain Dedication waiver (http://creativecommons.org/publicdomain/zero/1.0/) applies to the data made available in this article, unless otherwise stated in a credit line to the data. 
a

DTG vs.
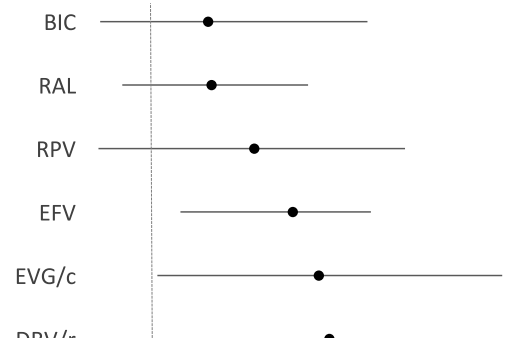

DRV/

ATV/r

$\mathrm{LPV} / \mathrm{r}$

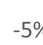

$-5 \%$

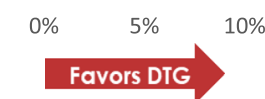

b

DTG vs.

LPV/

RAL

$\mathrm{EVG} / \mathrm{c}$

ATV/r

RPV

BIC

$\mathrm{DRV} / \mathrm{r}$

EFV
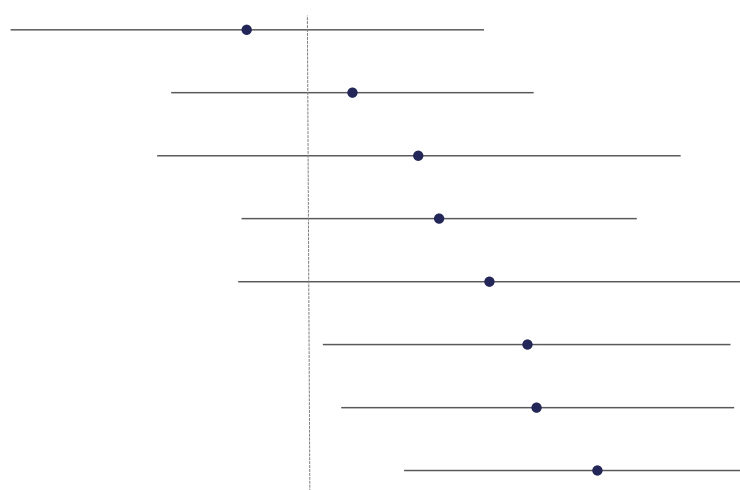

20 Favors DTC
RE Mean Diff (95\% Crl)

$2.7 \%(-2.7 \%, 10.6 \%)$

$2.9 \%(-1.6 \%, 7.7 \%)$

$5 \%(-2.8 \%, 12.5 \%)$

$6.9 \%(1.3 \%, 10.8 \%)$

$8.2 \%(0.2 \%, 17.4 \%)$

$8.7 \%(3.1 \%, 16 \%)$

$14.4 \%(6.5 \%, 23.3 \%)$

$19.9 \%(10.8 \%, 30.5 \%)$

$35 \%$

FE Mean Diff $(95 \% \mathrm{Crl})$

$-7.2(-34,19.8)$

$4.8(-15.8,25.4)$

$12.3(-17.4,42.1)$

$14.7(-7.8,37.1)$

$20.4(-8.2,49.1)$

$24.7(1.5,47.7)$

$25.7(3.5,48.1)$

$32.6(10.7,54.7)$

Fig. 3 Efficacy Results. a VS Risk Difference (RE model). b CD4 difference (FE model) 
DTG vs.

$\mathrm{LPV} / \mathrm{r}$
$\mathrm{DRV} / \mathrm{r}$

EFV

ATV/r

EVG/c

BIC

RAL

RPV
FE OR ( $95 \% \mathrm{Crl})$

$0.4(0.3,0.5)$

$0.5(0.4,0.7)$

$0.6(0.4,0.7)$

$0.6(0.4,0.7)$

$0.6(0.4,0.9)$

$0.7(0.5,1)$

$0.8(0.6,1)$

$0.8(0.6,1.2)$

1.5

Fig. 4 Odds of all-cause discontinuation (FE model)

\section{Author details}

${ }^{1}$ Pharmerit International, Berlin, Germany. ${ }^{2}$ Pharmerit International, Rotterdam, Netherlands. ${ }^{3}$ Pharmerit International, Bethesda, MD, USA. ${ }^{4}$ ViiV Healthcare, GSK House, 980 Great West Rd, Brentford, Middlesex TW8 9GS, UK.

Published online: 12 April 2021

\section{Reference}

1. Nickel K, et al. Comparative efficacy, safety and durability of dolutegravir relative to common core agents in treatment-naiive patients infected with HIV-1: an update on a systematic review and network meta-analysis. BMC Infect Dis. 2021;21:222. https://doi.org/10.1186/s12879-021-05850-0. 